\title{
Polish Teachers in Changing Reality
}

\author{
Olga Wyżga, Anna Mróz \\ Pedagogical University of Cracow, Cracow, Poland
}

\begin{abstract}
Authors of the text present Polish context of teachers' professional promotion and teachers' competencies. The text also has its empirical dimension — a research about teachers' sense of life quality has been done. There are teachers' expressions, collected and quoted during qualitative research. Teachers' thoughts are concerned about the sense of life quality in the context of working at lower secondary school.

Keywords: the sense of teachers' life quality, teacher, teachers' promotion, teachers' competencies, lifelong education
\end{abstract}

\section{Introduction}

Late modernity, postmodernism has brought a number of changes, which also relate to education. Those changes have a substantial impact on the everyday life of a professional various social groups, for example, teachers. Phenomena such as globalization, (hyper)consumerism, new threats (e.g. addiction of cyberspace, marginalization), the emphasis on the development of students' competencies, not only the transfer of knowledge, preparing the young generation to live in a society of permanent change (Sztompka, 2005) cause that teachers, in their daily work, are faced with the new challenges (Ocetkiewicz, 2015).

Teachers have to develop their own competencies and still acquire new competencies. The work of teachers is considered in terms of a mission; requirements for teachers made by society continue to grow and this is the way that teaching profession is so difficult. Working at school can help rise the sense of teachers' life quality, but it can also be the source of stress and disappointment.

\section{Teachers' Training and Their Professional Competencies}

The 21 st century school and the subject of its impact — the student — have different needs and requirements than in 20th century. Contemporary student is a digital native (Prensky, 2001) from the Y generation. He learns, works in a different way that his teacher does.

Teachers' functioning in a changing world requires knowledge, but also reflexivity, critical thinking, self-knowledge, insight into themselves. It results from their professional experiences (experiencing the change, unique and unpredictable teaching and educational situations, and also initiating the changes) (Lukasik, 2016).

The role of the teacher and the relation between the teacher and the student are changing. Teacher must be better prepared for that change. In Polish school before the education reform in 1999 the teacher was required, in

Olga Wyżga, Ph.D., Institute of Educational Sciences, Pedagogical University of Cracow, Cracow, Poland. Anna Mróz, Ph.D., Institute of Educational Sciences, Pedagogical University of Cracow, Cracow, Poland. 
the first place, to transfer of knowledge, often in a handed way (lectures, descriptions, stories, etc.) and to ensure the appropriate behavior of students. Few years ago the teacher did not have to compete with the mass media, today often he loses the battle for attention of the student. Today the teacher is no longer mediator of knowledge or its sole source-like it was in the past. Currently, we can observe the pedagogical inversion (Morbitzer, 2007) - in certain areas of life, students have far greater knowledge and competencies than the teachers and parents.

Currently, the teacher is required to be simultaneously an animator and instigator of independence of students, a diagnostician, a specialist in teaching aids, a trainer, a coach, a mediator, an example to follow and an advocate of new ways of working (Romanek, 2007). It is extremely difficult to meet the requirements of students, their parents, pedagogical supervision and school environment in the broad sense. The teachers must prepare their students for life in the world of the future, whose shape we are not currently able to predict.

Constantly changing reality of the school, its uniqueness, forces the teachers of tomorrow's education continuous improvement of already acquired and acquisition of new skills. The modern education raises the teacher new challenges and tasks, requires the revival of the teacher's profession ethos, to redefine the values, norms and practices, and restore between teacher and student relationships master and enlightened guide to the world of knowledge, which organizes the idea, derives from error, dispels doubts, draws attention to what is important (Denek, 2008). Towards episodic way of learning, hypertextual sources of knowledge, the teacher must be the one who leads young people, shaping their competencies of critical thinking, creativity thinking, forward-looking manner and the ability to cooperate in a heterogeneous group. These competencies will enable young people to actively shape the environment of their lives and their own future.

Development of science and changes in every area of life force teacher to do constant training in order to meet the demands posed by the contemporary education. Teacher education in Poland is a constant, and held in a formal, non-formal way; it is governed by the provisions of the Law on Higher Education (Polisz: Prawo o Szkolnictwie Wyższym, PSW) and the Education System Act (Polish: Ustawa o Systemie Oświaty, USO) and other regulations, issued on the basis of above mentioned laws.

The teachers of kindergartens, elementary schools and lower secondary schools may also be trained in the system of education in teacher training colleges (Polish: kolegium nauczycielskie) and foreign language teacher training colleges (Polish: nauczycielskie kolegium języków obcych). Teacher training colleges are taken over by universities and from 2012 do not accept new candidates.

In Poland, student at the university may choose many different courses of study. They can become specialist in various disciplines. They can also choose teacher specialty and acquire qualifications that enable them to work as a teacher of a subject in a specific type of schools. They can also complete teachers' qualifications after being graduated from the university, at the additional courses or postgraduate studies. Currently in Poland, teachers are trained in two specialties: the main, preparing teachers to teach one subject, applicable to the field of study and additional, preparing to teach a second subject (or organizing classes).

According to the standards of teacher training, preparing teachers to working in school includes five essential elements:

- The main field education, implemented in accordance with the standards of teaching for the relevant fields of study, including the acquisition of essential knowledge and skills; 
- The training of teachers, including the preparation in the field of psychology, pedagogy, didactics of the relevant school subject and preparing for the work of education, care and didactics;

- The teaching practice, preparing to work with the students, including the study of the organization and functioning of schools and other education institutions, and the acquisition and development of professional skills;

- The training in information technology, preparing for the use of new technologies in the teaching-learning process;

- The course of modern foreign language.

The specific character of the training allows teachers to gain multiple competencies that are necessary in the changing educational reality. Teacher competences are defined in different ways by many authors. The term competence is called the ability and willingness to perform tasks at a certain level. According to Marco Rieckmann, competence is individual disposition to self-organization, which involves cognitive, affective, volitional, and motivational elements, which are interactions of knowledge, skills and abilities, motivation and affective tendency, therefore, the competence is the ability to act (Rieckmann, 2012).

Strykowski, Strykowska and Pielachowski (2003) believe that competence is the ability and willingness to perform tasks at a certain level. This is a learnable ability to do things well; competencies are the efficiencies needed to deal with problems. Czerepaniak-Walczak (1997) says that the competence is a particular feature, expressed in demonstrating - at the standards set by the social level — skills for adequate behavior in the awareness of the need and what are the consequences of such behavior and to take responsibility for it.

In the cognitive concept of human, competencies are considered as indications of the activity of the individual ((Czerepaniak-Walczak, 1997). The term competence appears as a determinant of human activity; to be competent means being able to identify own activity as a rational and objective. Competence refers not to the activity itself, but rather to practical knowledge and skills for reflective action. The concept of competence should be referred to the "stand-mover", which means having such level of knowledge, practical skills, attitudes, and emotional involvement that guarantee the effective implementation of a specific type of order or task at any time (Czerepaniak-Walczak, 1997). Competence therefore means feature that allows a person to function well in a variety of situations. It enables the implementation of tasks in an efficient manner and at the appropriate level. Competencies are revealed by persons acting in specific situations, and with competencies human action becomes more effective. Depending on what sphere of human action concerns the activity, we can distinguish relatively broad categories of competencies, for example: cognitive competence, emotional, interpersonal, or professional school competencies, or narrow, specialized competencies, like managerial competence, effective managers' competencies, or "good teachers" competencies (Tucholska, 2007). With competence, it is possible to achieve success. Having competence is also an achievement in itself. Competencies are a higher stage of development of human potential and innate aptitudes and abilities. Acquired and developed — are developed and improved in the learning processes, both: individual (based on someone's own experience) learning and directed learning - in a particular educational system (Furmanek, 2000). Competence development lasts a lifetime and is then placed on the path of reconstruction-augmentation, by enriching existing skills and characteristics of the new - and not by replacing the one by the other. 
Therefore, the specific role of teachers who, in the course of their work, are obliged to continuously update and acquire new competencies, is to encourage their students to shape the ongoing development needs by acquiring new competencies. It is worth noting that the acquisition of competences is not the same as process of acquiring knowledge. Competencies can be learned (are learnable), but the teacher cannot teach them (they are not teachable). This raises the question of how they can be acquired through curricula.

Among the competencies that teachers — working with students at every level of education — should possess, the most important are: language, communication, cognitive, interpretative, auto-creation, interpersonal, social, informative, and professional competencies.

Language competencies (Chomsky, 1967) were defined in the 60s of the twentieth century by Noam Chomsky. Linguist described language competence in the category of mental structures: language skills are not something external to man; a knowledge about language means that someone has a certain structures of thought, consisting of a system of rules and regulations.

Communication competencies are associated with the ability to use language in a way that is adequate to the situation and the social role of speaking person (Hymes, 1980). This is reflected by the ability to "dialogue" way of being, in other words: the ability to be in dialogue with others and with himself. Dialogue is understood as a conversation with another person; a conversation that breaks the anonymity of expression and as an attempt to understand myself and what surrounds us together.

The cognitive competencies (Tucholska, 2007) express the ability to perceive the problem situation, its essence, creativity in finding solutions, creative thinking, fresh perspective on situations already known, the ability to make decisions and cognitive curiosity.

Associated with the sphere of emotions, emotional competencies are necessary to thrive in a changing environment. Person who acquired emotional competence (Goleman, 1999) is better adapted to life, his actions bring better results. These competencies include awareness and the ability to recognize someone's own and others' emotional states, their naming ability, the ability to postpone reactions, coping with negative emotions etc.

Dudzikowa (1993) indicates the competencies for interpretation as important, especially in the teacher's everyday work. This kind of competencies is responsible for "making the world intelligible". Thanks to them, a person can find and read the meaning of what surrounds him, and what he is experiencing. Competence for interpretation means the ability to understand the world.

Competencies for self-creation are associated with self-development and self-improvement processes, and expressed, inter alia, in the individual's ability to initiate and carry out tasks, in order to achieve such changes in the psyche, which person intends to comply with those desired at a given stage of development standards (Dylak, 1995).

Interpersonal competencies are critical when it comes to effectiveness in establishing and maintaining relationships with others. Their expressions is inter alia the ability to take the initiative, ability to work in a heterogeneous group, understanding the emotional states of others, the ability to resolve disputes and conflicts (Raven, 1984).

Each teacher must have social competencies (Matczak, 2001), which are understood as conditioning efficiency skills to cope with different types of social situations (Furmanek, 2000). They are acquired in the course of everyday social contacts. 
Professional competences (Kędzierska, 2007) assume having qualifications, which are considered as interdependent, confirmed by obtaining the proper certification, systems of knowledge, skills, and psychophysical features necessary to perform specific tasks, which entitle the person responsible for issuing opinions and judgments in a particular area. They consist of the skills necessary to work at a given position and those that affect the increase in the level of tasks. These include, for example, ease of learning new things, organizing jobs, saving effort and materials, teamwork and building the team.

Information competencies allow teachers to operate information more effectively (Kędzierska, 2007). Information has always been important to human, thus determining the fate of individual people and societies. Its value lies in the strength and extent of the changes they cause in the surrounding human reality. With the possession of information literacy it can be easier, faster, and more efficient to pursue goals and the tasks (Kędzierska, 2007).

Kwaśnica (2005) notes that for the proper functioning of teachers, they should acquire two types of competencies: practical-moral and technical.

The first group of competencies (practical-moral) is associated with empathy, understanding of the situation of the student, and above all, self-reflection and continuous verification of the quality of teacher's work, which in turn implies the moral responsibility of the teacher as a person supplying the students not only with knowledge, but also with the skills and attitudes. Moral competencies mean the ability to conduct-necessary in teaching - moral reflection. Their participation in the life of every human being is expressed in questions about the justification of moral reflections. Having practical-moral competencies enables the development of technical competencies, which are understood as a part of teacher preparation. Without practical-moral competencies, and therefore in isolation from reflective skills and experience of the student's own situation (empathy), technical competencies can be a tool to threaten the development of the individual and society, and not the educational method. Practical-moral competencies are the basis; having them enables teacher to work in school.

Strykowski (2005) notes that teachers' competencies are considered in three dimensions: substantive competencies, didactic-methodical and educational competencies. This division corresponds to the classification of teachers' competencies proposed by the OECD, in which the authors present three of the most important - in their opinion - groups of competencies necessary for the efficient work of the teacher at every level of education:

- subject competencies - primarily related to knowledge;

- methodological competencies - related to the way of transfer of knowledge and action;

- social competencies;

- personal competencies - related with attitudes, beliefs, and motivation (Rychen, 2003).

A competent teacher can help students to deal with uncertainty, ambiguity. It is extremely important to note that the school means meeting people. That personalistic point of view, that in the school the most important is the human, undoubtedly affects the activity of teachers who not only teach but also educate. Education in the school takes the form of contacts, which is characterized by responsibility, ethical activity as an educator, but sometimes practical ideology (Wyżga, 2007).

\section{The Professional Promotion of Teacher in Poland}

Another example of teacher training in Poland is the system of career advancement. Since 2000, teachers are 
obligated to career advancement (both in public schools and non-public). Since the introduction of the Regulation of the Minister of National Education and Sport on teachers' promotion of 3rd August 2000, teachers' professional advancement is associated with an increase of the qualifications and acquisition of new skills. The promotion is the goal of the majority of teachers working in different educational institutions.

There are five stages of teacher promotion in Poland. First of all, after university graduation, the teacher becomes the "trainee", who teaches for one or two years. Success at this level, plus an interview before a committee consisting of the trainee's mentor, school's director, faculty chair of the subject, and a trade union representative selected by the trainee, enhances the trainee to the next level — the "contract teacher". As a contract teacher, he works for at least three years. Thereafter, passing an examination, he can get the status of "nominated teacher". Three good years must be completed at this level, plus an interview with a committee consisting of the school's director or assistant director, three experts from the Ministry of Education, and a trade union representative. The fourth level, "certified teacher", is where most careers end. Some, however, manage to reach the fifth level, which is honorary, "professor of education" (Szlosek, 2014).

Every teacher's career starts with the trainee degree. This category receives a teacher employed by the headmaster at the beginning of the school year to go through a nine-month internship, completed a promotion to a higher grade: a contract teacher. The director shall assign the intern supervisor (of teachers assigned or certified), who helps him in the preparation and implementation of the development plan and prepare a draft evaluation of teacher's professional achievements for the period of internship. At the end of the year, the trainee teacher must apply to the director to start the qualification procedure. Then, the headmaster appoints a selection committee composed of:

(a) a director or deputy director, who serves as chairman of the committee;

(b) the team leader of the subject team;

(c) the tutor.

Following a favorable opinion of the committee, the candidate receives the title of contract teacher.

After two years receiving the degree of contract teacher, the teacher could begin the process of applying for promotion to the next level. As in the case of a trainee teacher, the headmaster chooses the tutor, who helps the contract teacher. Contract teacher prepares a plan for the development of vocational training period. The duty of contract teacher applying for a promotion is to get involved in teaching projects, organized by the school, training to familiarize himself/herself with the legislation related to education, training, establishing close contacts with students, getting to know the mechanisms of the school. If the contract teacher passes the examination towards the commission, he/she becomes a nominated teacher.

At least a year after giving it a degree of nominated teacher, the teacher can begin efforts to obtain the title of certified teacher.

The certified teacher who wants to become certified teacher, has to show extensive professional achievements, especially those obtained after the previous promotion. During the training period, the teacher must improve his/her teaching skills and acquire new competences in this field, positively influence the opinion of the school, take an active part in extra-curricular activities.

In 2009, almost half of the Polish teachers were certified teachers. The reason for this is that when the promotion system was implemented, teachers with long work experience automatically received a degree of 
certified teacher. The average age of achieving the degree of certified teacher is about 40 years (that is, several years before the end of teachers' careers).

\section{Sense of Teachers’ Life Quality}

Nowadays being a teacher is remarkably hard, demanding and responsible profession. It requires from teachers not only a lifelong education, professional promotion, but also taking indirectly responsibility for the life's successes of their pupils. All these things cause that many teachers have a professional burnout or complain about quality of their lives.

An attempt of uniform explanation of "life's quality" definition brings many intricacies, due to its interdisciplinary nature. This issue is attended by several disciplines, for instance medicine, psychology, pedagogy, sociology, and economics. Representatives of these branches of knowledge, in their deliberations about human life's quality refer to every aspect of human existence, which is treated in holistic way, both from objective perspective and subjective (Daszykowska, 2007).

Pedagogy, most frequently, defines "life's quality" as "sense of life satisfaction expressed by possibility of forming multi-dimensional development, human's self-creation and realization of his aspirations and life aims according to accepted values and expectations with simultaneous allowing for material elements of social status" (Daszykowska, 2007).

Nowadays in social sciences very valid role ascribes to subjective research of life's quality sense. The main point of researches has been shifted from the diagnosis of objective's indications towards determinants of individual evaluation criteria.

Wiatrowska (2009) has completed this concept of definition, which says that life's quality, in subjective sense, consists of subjective factors, which means well-being and people's judge in range of their own physical, material, psychosocial, and also existential dimensions.

Blending into this stream of research, it was decided to recognize the reality concerning about sense of life's quality of active professionally polish teachers from Małopolska county.

In this purpose, it was used strategy of qualitative researches and conducted narrative interview in the group of 10 teachers. The selection of respondents was intentional. During the selection the criteria were:

- seniority (10-20 years), which is period of employment, which allows teacher to accomplish some experience, obtaining specific degree of professional promotion, material status;

- school's type-lower secondary school, which in accordance with project of new educational reform in Poland will disappear from school's system structure.

Among the disposals of the interview, it included questions concerning about the evaluation and assessment, which were selected on purposely for compilation some domains of the six basis areas of life quality, indicated by WHO, that is respondents' mental and psychological state, their level of independence, social relations, effect of environment, and spiritual state. For this article, it used only those parts of interviews, which were connected with sense of own life quality but in a perspective of professional activity.

At the beginning of the meetings the respondents were asked for an explanation of life's quality definition.

In analyzed respondents' statements, most often, there appears definition like "satisfactory, good life", "sense of accomplishment from what I have achieved during my life: home, family, job", "the feeling that 
everything I am doing makes a sense", "economics' satisfaction and possibility of living on appropriate level", "life's quality depends on health and happiness in life".

From the respondents' point of view, life's quality has the biggest impact on health and family. However on the second place of things that may affect on life's quality is professional career and on third place is their economic situation. In conducted interviews, the respondents were asked about appraisal and satisfaction of private life, family life, about estimate of life's quality for health reason. But also they were asked due to the subject of this study and as it was already mentioned, in the article were used only those parts of narration which relate to respondents' opinion on their own life's quality sense, resulting from job satisfaction and factors, which determinate this satisfaction or lack of it.

To the most valuable and interesting statements regarding job satisfaction from professional work, we can include:

16 years ago, I consciously chose the teaching profession and I have never regretted this decision. I like working with children, due to the fact that they constantly teach me something new and surprise me (F, LSS, 16). ${ }^{1}$

In work, as usual, it tends to be different, but despite that I still can say that I have satisfaction from what I am doing. Of course, I have got more and more duties and responsibilities, but because of amazing atmosphere at workplace and nice workmates compensate me all difficulties. (F, LSS, 11)

I am satisfied about my job, maybe because I have always treated it as specific vocation. That is why I get upset because of definition that pupils/students and their parents are educational customers. In any way I do not feel like a seller in the shop... (F, LSS, 19)

I am pleased of my life and my job - I do what I like and what I can do the best. (F, LSS, 12)

I am descended from family with teachers traditions and I cannot imagine any other place on Earth for my professional career, if not a school. (F, LSS, 15)

Despite almost 18 years of my teaching career I do not feel that majority. I am person full of energy and satisfaction. Probably, it is because since I was a child I repeated to myself that I want to work in school. Of course, it occurs hard and difficult days, sometimes I even asked myself if this is not a burnout, but then after work I get on a bike and drive ahead (...) and in the next morning I wake up full of vigor and willingness to work. (F, LSS, 18)

All examined teachers were content because of their job, which has positive impact on their life's quality. The respondents in interviews pointed out factors, which determinate work's satisfaction. They included the main factors: good atmosphere and appropriate interpersonal relations at workplace. Interpersonal relation at workplace may be defined as a relation combined different subjects, functioning in educational reality (teachers, students, parents, and management) and affecting on each other.

I am aware that in any situation I can count on support and help from my colleagues. (F, LSS, 10)

Despite various difficulties, for instance hourly deficiencies, we constitute a harmonious team, which seeks for win-win solutions for teachers and does not argue with each other. (F, LSS, 12)

Majority of teaching staff in our school are people, who care about great atmosphere. These are people with some work experience and you can honestly talk with each other without arguing. (F, LSS, 14)

\footnotetext{
${ }^{1}$ Transcript means: first letter refers to gender, type of school (LSS means lower secondary school) and number refers to seniority.
} 
On satisfying life has impact not only relations with colleagues, but also relations with a principal of a school. His management style, communication's skills are those factors, which determine work's quality and life's quality. That is what clearly indicated examined teachers in their responses.

Our Principal is a great man. He knows the school's specification. He is an amazing manager, because he is able to speak effectively with clerks of the authority responsible for the school. But above all of this he is human. He is able to praise for the success, but he also notices mistakes. However in every situation he is fair in his judgments or assessments. Under his leadership I feel safe at my work. (F, LSS, 16)

Undoubtedly, a principal's attitude has impact on my satisfaction from my professional life. He is factual, conscientious, objective and fair person, and what is the most important, who does not like rumors and gossips. (F, LSS, 18)

We had magnificent principal, unfortunately for us she retired on well-deserved pension. For two years we are having a new principal. In my opinion he is a manager, clerk, who does see neither a student nor a teacher. For him count only effects connected with work, like results of school-leaving exams, school's position in the different rankings and amount of subsidy, which school will receive. And if someone does not appeal to something, as he used to say that he does not keep anybody here in force. In this atmosphere, it is hard to tell about life's comfort. (F, LSS, 10)

Undoubtedly, on level of life satisfaction from job done by teacher huge meaning has professional development and possibility of professional promotion. The professional development is constant increase and individual's changes of abilities to specified types of professional behavior. While, in the contrary the professional promotion can be defined as process of improving qualification by teachers. This promotion is held on four gradual ways:

- Trainee teacher;

- Contract teacher;

- Appointed teacher;

- Qualified teacher.

Teacher's job is an example of this type of profession, in which constant training and complementation of qualifications are some kind of norms. It results from, not only a necessity of obtaining professional advancements' degrees, but also from the character of this job. These issues are regulated by basic documents such as “The Teacher's Charter and decree of National Education's Minister”, dated on 1 March 2013 concerned about obtaining professional promotion by teachers. The respondents also noticed this.

Our job requires persistent complementation of ours qualifications, but I like to learn as it makes me feel more valuable and rejuvenates me. (F, LSS, 18)

Due to the fact, that I have to pass on knowledge, I cannot be behind my students. Unfortunately, sometimes my professional improvement is held at the expense of my spare time. Nevertheless, awareness that new skills and experiences would help me in my work is enough for me... For now... (F, LSS, 19)

In our school we developed an internal system of professional trainings. The principal invites different types of specialist to these trainings, but what is more, we are able to share our own experience from different forms of self-development, in which we have participated. (F, LSS, 14)

An example of professional trainings is another stage of professional career. At the beginning, I really did not like it, but in retrospect I can see that it was a great solution. A promotion gives me a greater sense of confidence in my career and contributes to improvement of teacher's financial matter. (F, LSS, 12) 
Another factor, which affects on sense of examined teachers' life quality is sense of teachers' financial satisfaction. Indubitably, human work is value in itself and constitutes source of development, but also it is impossible to forget about economics function, which allows to satisfy any needs or requirements, to obtain higher standard of living and at the same time to increase level of own life's quality.

Examined teachers also have some thoughts in this subject:

At the time when I was doing every degree of professional's promotion I knew that I am not only develop myself, but also I will have a chance to earn bigger amount of money in school. (F, LSS, 18)

In comparison with the beginning of my work I am earning more and I and my family are living on a higher standard. I am aware that I can be allowed myself not only for a divergent forms of trainings, but first and foremost I able to have a nice holidays or make a redecoration in my apartment. (F, LSS, 19)

Of course, an amount of my salary is increasing along with professional promotion, but as far as I am concerned teachers in Poland are still financially underestimated for their contribution to work and stress, which involves this job. (F, LSS, 12)

Among many determinants of building a sense of life quality of polish teachers we cannot omit stress, which is unfortunately present in modern people's lives. Professional stress is some kind of mental discomforts that individual experiences in a moment of disagreement between requirements, which are imposed to him, and single or situational resources (Chmiel, 2003).

Regrettably, as stated by the respondents, teacher job associates to them, more and more with stress.

I have been working in school for 19 years and I thought that I will work there until my retirement, but today I am afraid that I am going to be unemployed when Ministry will close junior high schools. Working in this tension causes that I have less willingness to work. (F,LSS, 19)

As a consequence of teacher's multitude of additional duties, the whole time I have got a feeling that I did not manage to do something and it torment me. (F, LSS, 15)

I like working with youth, but what I do not like is contacting with their parents. They are very demanding and what is more I feel that they treat me like a human of lower category. It is very stressful situation for me (F, JHS, 10)

\section{Conclusion}

The main purpose of this article was a trail of polish teachers' characteristic in changing world. On the surface it may appear as an easy task, however it is not. Most people thinking about teacher's profession assume that he is working at school, teaching, bringing up, and caring for children and youth. Infrequently people think about that teacher must persistently develop himself, train his qualifications, improve his competences, gain particular degree of professional promotion, since he is not only just a person who passes on his knowledge, but also an adviser, a specialist who helps in self-reliant discovery of knowledge by student. During working with people, a teacher is also run the risk of functioning in hard, stressful situations. All these mentioned before factors, affect inclusively on sense of life's quality of modern teacher. Taking everything into consideration, it is worth to repeat with Zofia Kucówna, an outstanding polish actress and educator:

Work of educator is one of the most thankless professions in the world. You are teaching contrary to who you are teaching (...) And if in this profession is something from vocation, it is that you are teaching persistently despite everything, even if you know that you will be appreciated by your student only in a future. (1900: 16) 


\section{References}

Białecki, I. (2003). Teacher education in Poland. Institutional approaches to teacher education within higher education in Europe: current models and new developments. Bukarest: UNESCO-CEPES.

Bukowski, M. (red.). (2009). Zatrudnienie w Polsce 2007. Bezpieczeństwo na elastycznym rynku pracy (Employment in Poland 2007. Security in a flexible labor market). Warszawa: Instytut Badań Strukturalnych.

Bukowski, M. (red.). (2010). Zatrudnienie w Polsce 2008. Praca w cyklu zycia (Employment in Poland 2008. Work in a lifecycle). Warszawa: Instytut Badań Strukturalnych.

Chmiel, N. (2003). Psychologia pracy I organizacji (The psychology of work and organization). Gdańsk: GWO.

CODN. (2009). Nauczyciele we wrześniu 2008 roku. Stan i struktura zatrudnienia (Teachers in Semptember 2008. The condition and structure of employment). Warszawa: Centralny Ośrodek Doskonalenia Nauczycieli.

Czerepaniak-Walczak, M. (1993). Aspekty i źródła profesjonalnej refleksji nauczyciela (Aspects and sources of professional teacher reflection). Toruń: Edytor.

Chomsky, N. (1967). The formal nature of language. In E. Lennberg (Ed.), Biological foundations of language (pp. 397-442). New York: J. Wiley \& Sons, Inc.

Daszykowska, J. (2007). Jakość życia w perspektywie pedagogicznej (Quality of life in a pedagogical perspective). Kraków: Impuls.

Denek, K. (2008). Przewodnik po świecie wiedzy, wartości i życia (Guide to the world of knowledge, values and life). In K. Żegnałek (red.), Kompetencje nauczyciela edukacji poczattowej (The competencies of early education teachers). Warszawa: Wydawnictwo Wyższej Szkoły Pedagogicznej TWP.

Dudzikowa, M. (1993). Praca młodzieży nad soba (Youth work on themself). Warszawa: Wydawnictwa Szkolne i Pedagogiczne.

Dylak S. (1995). Wizualizacja w kształceniu nauczycieli (Visualization in teacher education). Poznań: Wydanictwo Naukowe UAM.

Eurydice. (2009). Kluczowe dane o edukacji w Europie 2009 (Key data on education in Europe 2009). Fundacja Rozwoju Systemu Edukacji.

Furmanek, W. (2000). Podstawy edukacji zawodowej (Basics of vocational education). Rzeszów: Wydawnictwo Oświatowe FOSZE.

Goleman, D. (1999). Inteligencja emocjonalna w praktyce (Working with emotional intelligence). Poznań: Media Rodzina.

GUS. (2009). Struktura wynagrodzeń wedtug zawodów w październiku 2008 (The structure of wages and salaries by occupations in October 2008). Warszawa: Główny Urząd Statystyczny.

Hymes, D. (1980). Socjolingwistyka i etnografia mówienia (Sociolinguistics and ethnography of speaking). In M. Głowiński (Ed.), Język $i$ spoleczeństwo (Language and Society). Warszwa: Czytelnik.

Kędzierska, B. (2007). Kompetencje informacyjne w kształceniu ustawicznym (Information competences in lifelong learning). Warszawa: Instytut Badań Edukacyjnych.

Kucówna, Z. (1990). Zatrzymać czas (To stop the time). Białystok: Krajowa Agencja Wydawnicza.

Kwaśnica, R. (2005). Wprowadzenie do myślenia o nauczycielu (Introduction to reflection about the teacher). In B. Śliwerski and Z. Kwieciński (Eds.), Pedagogika (Pedagogy) (vol. 2). Warszawa: Wydawnictwo Naukowe PWN.

Łukasik, J. (2016). Poznać siebie i dbać o rozwój w drodze do sukcesu (To get to know yourself and to care about personal deveopment). Kraków: Wydawnictwo WAM.

Matczak, A. (2001) Różne oblicza inteligencji: funkcjonowanie intelektu a osobowość (Different faces of the intelligence: functioning of the intellect and personality). In: Studia Psychologica $\mathrm{nr} 2$.

McKinsey. (2007). How the world's best-performing school systems come out on top. New York: McKinsey \& Company, Inc..

Morbitzer J. (2007). Autorytet nauczyciela w społeczeństwie informacyjnym (Teacher's authority in the information society). In J. Morbitzer (red.), Komputer w edukacji: 17. ogólnopolskie sympozjum naukowe (Computer in education: 17th nationwide scientific symposium). Kraków: Wydawnictwo Wyższej Szkoły Pedagogicznej w Krakowie.

Ocetkiewicz, I. (2015). Global education as a challenge in the process of teacher training. In Edukácia (Vol. 1, No. 2). http://www.upjs.sk/public/media/11267/21.pdf [access: 10.10.2016]

Piwowarski, R., \& Krawczyk, M. (2009). TALIS. Nauczanie-wyniki badań 2008. Polska na tle międzynarodowym (Teaching-research results 2008. Poland on the international background). Warszawa: Ministerstwo Edukacji Narodowej i Instytut Badań Edukacyjnych. 
Prensky, M. (2001). Digital natives, $\quad$ digital immigrant. http://www.marcprensky.com/writing/Prensky\%20-\%20Digital\%20Natives,\%20Digital\%20Immigrants\%20-\%20Part1.pdf [access: 12.11.2016]

Putkiewicz, E., Murawska, B., \& Dolata, R. (2005). Wsparcie rozwoju zawodowego a potrzeby nauczycieli w tym zakresie (Support for professional development and the needs of teachers in this area). Warszawa: Instytut Spraw Publicznych.

Rieckmann, M. (2012). Future-oriented higher education: Which key competencies should be fostered through university teaching and learning? Futures, 44(2), 127-135.

Romanek, B. (2007). Nauczyciel wobec wyzwań współczesnej edukacji (A teacher facing the challenges of modern education). In E. Rogacki (Ed.), Refleksje nad wspótczesnq pedagogikq w Polsce (Reflections on contemporary pedagogy in Poland). Białystok.

Rychen, D. (2003). Key competencies: Meeting important challenges in life. In D. Rychen and L. Salganik (Eds.), Key competencies for a successful life and well-functioning society. Toronto-Bern: Hogrefe \& Huber, Cambridge/MA.

Strykowski, W., Strykowska, J., \& Pielachowski, J. (2003). Kompetencje nauczyciela szkoły wspótczesnej (Competences of a modern school teacher). Poznań: Oficyna Ekonomiczna Wydawnictwa empi Sc.

Strykowski, W. (2005). Kompetencje współczesnego nauczyciela (Competences of a modern teacher). In Neodidagmata (No. 27/28). Poznań.

Szlosek, F. (2014). Rozwój zawodowy nauczyciela (Teacher's professional development). In Polityka Spoleczna (Social Politics) (No. 3).

Sztompka, P. (2005). Socjologia zmian spolecznych (Sociology of the social changes). Kraków: Wydawnictwo Znak..

Tucholska, K. (2007). Kompetencje temporalne jako wyznacznik dobrego funkcjonowania (Temporal competencies as a determinant of well-being). Lublin: Towarzystwo Naukowe Katolickiego Uniwersytetu w Lublinie.

Wiatrowska, A. (2009). Jakość życia w zaburzeniach odżywiania (Quality of life in eating disorders). Lublin: Wydawnictwo UMCS.

Wyżga, O. (2007). Nauczanie wychowujace. Założenia a szkolna rzeczywistość (Teaching upbringing. Assumptions and school reality). Kraków: Wydawnictwo Naukowe Akademii Pedagogicznej. 